Teologia i Moralność, volumen 16(2021), numer 2(30)

doi: 10.14746/TIM.2021.30.2.12

ORCID: 0000-0001-7965-4266

\author{
MARCIN SZCZODRY \\ Uniwersytet Szczeciński \\ Instytut Nauk Teologicznych
}

\title{
Etyczny wymiar badań nad przygotowaniem i zastosowaniem szczepionki przeciw COVID-19
}

\section{Wstęp}

Pandemia wywołana koronawirusem SARS-CoV-2 uruchomiła wyścig w celu znalezienia szczepionki na COVID-19. Światowa Organizacja Zdrowia zarejestrowała ponad 200 różnych podmiotów, które prowadzą badania nad szczepionką. Coraz więcej potencjalnych szczepionek znajduje się w zaawansowanych badaniach klinicznych III fazy na ludziach, kilka z nich zakończyło już fazę badań klinicznych i czeka na rejestrację, która umożliwi wejście na rynek i dostępność w sprzedaży. Pod koniec 2020 r. zostały zatwierdzone pierwsze szczepionki, co umożliwiło rozpoczęcie szczepień na szeroką skalę. Pojawiła się nadzieja, że antidotum na chorobę COVID-19 wkrótce spowoduje opanowanie pandemii, której skutki dotknęły cały świat. Papieska Rada ds. Duszpasterstwa Służby Zdrowia zauważa, iż ,z punktu widzenia profilaktyki chorób zakaźnych przygotowanie szczepionek oraz ich stosowanie w zwalczaniu tych zakażeń poprzez obowiązkowe uodpornianie całych populacji, których to dotyczy, jest niewątpliwie postępowaniem pozytywnym" (Papieska Rada ds. Duszpasterstwa Służby Zdrowia 2017, 69). Opracowanie każdej nowej szczepionki to jednak bardzo długi i złożony proces. Zanim prototyp szczepionki zostanie wypróbowany na ludziach w badaniach klinicznych, musi przejść etap badań przedklinicznych w laboratorium i na zwierzętach. Czy w tym wyścigu po szczepionkę obowiązują jakieś reguły etyczne? Czy możemy być pewni, że produkt leczniczy, który otrzymamy, nie będzie budził wątpliwości moralnych? Jakie kryteria należy wziąć pod uwagę, aby proces powstania szczepionki oraz jej użycie uznać za etycznie godziwe? 
Prace nad przygotowaniem szczepionki przeciw COVID-19 na nowo otworzyły pytania natury etycznej, które są aktualne przy każdorazowo podejmowanych badaniach i poszukiwaniach w celu znalezienia adekwatnej szczepionki na choroby zakaźne, na które brak jeszcze skutecznej ochrony. W niniejszej pracy przedstawimy problemy etyczne związane z procesem przygotowania szczepionki w fazie eksperymentów i badań oraz kwestie etyczne związane z dystrybucją i dostępnością szczepień, gdy szczepionka jest już dostępna na rynku. Na tle bieżącej dyskusji, w której zaangażowani są naukowcy, lekarze, bioetycy, politycy, zostanie przedstawione stanowisko Kościoła katolickiego, wyrażone w wypowiedziach papieży, dokumentach dykasterii watykańskich, interwencjach wybranych episkopatów krajowych oraz biskupów. Szczegółowy problem badawczy, który wyłania się w kontekście pandemii koronawirusa, wiąże się z pytaniem, czy obecna sytuacja spowodowała pogłębienie tematu szczepień z perspektywy moralnej w wypowiedziach Urzędu Nauczycielskiego Kościoła?

\section{Podstawowe zasady etyczne w fazie badań i eksperymentów: pro- porcjonalność ryzyka i wyrażenie zgody}

Opracowanie nowej i skutecznej szczepionki to bardzo złożony i czasochłonny proces. Wymaga nakładu wielu środków finansowych, zaangażowania naukowców, przeprowadzenia badań i eksperymentów. Zanim gotowy produkt trafi na rynek i będzie powszechnie dostępny, musi przejść szereg badań i eksperymentów, które wykażą jego skuteczność w zapobieganiu chorobie. Ocena skuteczności szczepionki przebiega w kilku etapach. W pierwszym przeprowadza się badania przedkliniczne, które polegają na eksperymentach laboratoryjnych, także z wykorzystaniem zwierząt. Na kolejnych etapach przeprowadza się badania kliniczne na ludziach $w$ trzech fazach. W fazie I ocenia się profil bezpieczeństwa, dawkę i schemat podawania potencjalnej szczepionki na małej grupie ochotników. W fazie II badanie kliniczne zostaje rozszerzone na populację docelową, biorąc pod uwagę odpowiednie cechy osób (takie jak: wiek, stan zdrowia fizycznego), dla których przeznaczona będzie nowa szczepionka. W fazie III szczepionka podawana jest dużej ilości osób (kilku tysiącom ochotników) w wybranej populacji. Testuje się ją pod kątem skuteczności i bezpieczeństwa. Gdy przeprowadzone badania wykażą skuteczność szczepionki, zostaje ona zarejestrowana oraz wprowadzona na rynek. Dalsze obserwacje i badania epidemiologiczne prowadzone w celu zweryfikowania zmian zachorowań w populacji po wprowadzeniu na rynek szczepionki pozwalają ocenić, jak szczepienia działają w praktyce.

Na poszczególnych etapach badań i eksperymentów mogą pojawić się różne problemy etyczne. Szczegółowe wytyczne dotyczące etycznych aspektów badań i eksperymentów z udziałem ludzi znaleźć możemy w międzynarodowych doku- 
mentach Światowej Organizacji Zdrowia (World Health Organization 2000) oraz Międzynarodowej Rady Harmonizacji Wymagań Technicznych Dla Rejestracji Produktów Leczniczych Stosowanych u Ludzi (2016). Również w dokumentach Kościoła katolickiego, które podejmują szczegółowe kwestie bioetyczne, znajdujemy podstawowe zasady dotyczące przeprowadzania badań i eksperymentów na ludziach (Kongregacja Nauki Wiary 1987; 2008; Papieska Rada ds. Duszpasterstwa Służby Zdrowia 2017). Warto zauważyć, że do instrukcji Kongregacji Nauki Wiary Donum vitae i Dignitas personae odwołują się wielokrotnie dokumenty watykańskie powstałe w czasie pandemii (Commissione Vaticana COVID-19 e Pontificia Accademia per la Vita 2020; Kongregacja Nauki Wiary 2020).

Fundamentalne założenie przy podejmowaniu jakichkolwiek badań i eksperymentów z udziałem ludzi wymaga, aby były one ukierunkowane na promowanie ludzkiego dobra. Niemoralne będzie więc każde badanie, które sprzeciwia się prawdziwemu dobru osoby i traktuje człowieka czysto instrumentalnie. Nie tylko cele, ale także metody badań i stosowane środki muszą zawsze wyrażać poszanowanie godności każdej istoty ludzkiej, na każdym etapie jej rozwoju i w każdej fazie eksperymentu (Papieska Rada ds. Duszpasterstwa Służby Zdrowia 2017, 100; Jan Paweł II 2003, 590-591).

W badaniach należy przede wszystkim uwzględnić czynnik ryzyka, ponieważ każdy eksperyment ze swej natury wiąże się z ryzykiem. W fazie klinicznej eksperymentu na człowieku ryzyko to powinno być proporcjonalne do przewidywanych korzyści i gwarantować zachowanie integralności podmiotu, na którym dokonuje się eksperymentu. Gdyby proporcje ryzyka i przewidywanych korzyści uległy zachwianiu, stwarzając nieproporcjonalne niebezpieczeństwo dla uczestników eksperymentu, powinien on zostać wstrzymany (Sgreccia 2007, 782).

Kolejnym warunkiem etyczności eksperymentów jest uzyskanie dobrowolnej i świadomej zgody osób biorących udział w eksperymencie. Osoby takie powinny być szczegółowo poinformowane o sposobie przeprowadzenia eksperymentu, o zastosowanych procedurach kontrolnych, o przewidywanych korzyściach, o istniejącym ryzyku nieprzewidywalnych skutków ubocznych, o możliwości wycofania swojej zgody i przerwaniu eksperymentu (Leone 2007, 270-272).

Badania i eksperymenty na embrionach i płodach ludzkich winny być podporządkowane normom etycznym odnoszącym się do dziecka już narodzonego i każdego podmiotu ludzkiego (Papieska Rada ds. Duszpasterstwa Służby Zdrowia 2017, 106). 


\section{Problem metodologii i organizacji badań medycznych $w$ trakcie pandemii}

Wraz z rozwojem pandemii COVID-19 uwidoczniła się wielka presja na jak najszybsze wytworzenie leków i szczepionek przeciwko wirusowi. Dotychczasowe procedury i wytyczne okazały się niewystarczające, aby przyśpieszyć prace nad szczepionką, której opracowanie w normalnych warunkach zajmuje kilka lub kilkanaście lat. Naukowcy, komisje etyczne oraz prawodawcy podjęli szereg kroków, aby zmodyfikować procesy badawcze tak, aby szczepionka pojawiła się w najkrótszym możliwym czasie. Światowa Organizacja Zdrowia wydała odpowiednie dokumenty, które normowały zasady prowadzonych badań w specyficznym kontekście ogólnoświatowej pandemii (World Health Organization 2020a; 2020 b; 2020c). Należy zauważyć, iż tradycyjne procedury badawcze bywały wielokrotnie w czasie pandemii radykalnie modyfikowane. W celu przyśpieszenia badań niektóre szczepionki były testowane z udziałem ludzi bez danych z badań przedklinicznych, co zwiększało ryzyko dla wolontariuszy biorących udział w badaniach. W testach niektórych szczepionek podjęto decyzję o kontrolowanym zarażeniu zdrowych osób wirusem - praktyka dyskutowana już wcześniej przy poszukiwaniu szczepionek przeciwko malarii, Eboli czy wirusowi Zika. Marcin Waligóra określa takie działania mianem ,,akceleratorów metodologicznych i organizacyjnych" (Waligóra 2020). Czy takie podejście do problemu jest uprawnione? Czy stan pandemii pozwala naukowcom, prawodawcom, społeczeństwu, aby przyśpieszając badania, podejmowali ryzyko, że zostanie obniżona ich jakość, rzetelność, a tym samym może dojść do nadużyć związanych z wypuszczeniem na rynek produktu, który niesie złudną nadzieję w walce $\mathrm{z}$ chorobą? Opinie w tej kwestii są podzielone. Jedni przestrzegają przed zbyt pochopnym uproszczeniem wypracowanych dotychczas procedur, argumentując, iż kryzys związany z pandemią nie powinien być podstawą do obniżenia standardów naukowych (London i Kimmelman 2020). Inni wskazują na konieczność i zachęcają do prowadzenia badań o wyższym, niż zazwyczaj, dopuszczalnym ryzyku (Eyal, Lipsitch i Smith 2020; Plotkin i Caplan 2020; Shah i in. 2020). Marcin Waligóra stawia tezę, iż w szczególnych warunkach pandemii zmieniają się dwa kluczowe elementy etycznej oceny badań klinicznych poszukujących leków przeciw COVID-19: wartość społeczna badań klinicznych oraz sposób prowadzenia analizy ryzyka i korzyści tych badań. Akceptacja społeczna dla bardziej ryzykownych badań klinicznych nad szczepionką oraz lekami przeciw COVID-19 zwiększa się w czasie pandemii, co znajduje wyraz chociażby w dużej liczbie wolontariuszy zgadzających się na kontrolowane zarażenie wirusem w ramach testów nad szczepionką (Waligóra 2020). 
ETYCZNY WYMIAR BADAŃ NAD PRZYGOTOWANIEM I ZASTOSOWANIEM SZCZEPIONKI... 219

\section{Problem pochodzenia materiału biologicznego wykorzystywanego do produkcji szczepionki}

W kilku prototypach szczepionek, które są w zaawansowanej fazie badań klinicznych na ludziach, wykorzystuje się materiał biologiczny pochodzący z komórek macierzystych abortowanych płodów ludzkich. Tak jest m.in. ze szczepionką opracowaną przez University of Oxford i koncern Astra Zeneca, której podawanie rozpoczęło się na początku 2021 r. w Wielkiej Brytanii. Podpisanie umowy z koncernem farmaceutycznym przez niektóre rządy (np. USA, Australii) na zakup tej szczepionki wzbudziło dyskusję nad etycznymi konsekwencjami takiego wyboru. Polityczne decyzje rządów sprowokowały debatę bioetyczną (Watt 2020) oraz skłoniły przedstawicieli Kościoła do zajęcia stanowiska w tej sprawie (Comensoli 2020; Fisher 2020; Commissione Vaticana COVID-19 e Pontificia Accademia per la Vita 2020; Kongregacja Nauki Wiary 2020; Zespół Ekspertów ds. Bioetycznych Konferencji Episkopatu Polski 2020).

W liście do premiera Australii trzech biskupów (katolicki, prawosławny i anglikański) napisało, iż wykorzystanie komórek pochodzących z aborcji do produkcji szczepionki przeciw COVID-19 jest głęboko niemoralne (Davies, Fisher i Makarios 2020). Hierarchowie zauważają, iż choć dla niektórych nie stanowi to problemu etycznego, to dla wielu stwarza jednak poważny problem moralny, ponieważ zauważają bezpośrednią zależność między zakończeniem życia ludzkiego w drodze aborcji, poprzez hodowlę komórkową, aż do użycia linii komórkowych do produkcji szczepionki. Nawet jeśli komórki były rozmnażane przez lata w laboratorium, instytucji dalekiej od przeprowadzania aborcji, ta linia połączenia pozostaje. Biskupi zaapelowali do rządu, aby szczepionka opracowana przy wykorzystaniu komórek pochodzących $\mathrm{z}$ abortowanych płodów nie była obowiązkowa oraz aby władze nie wywierały presji na Australijczyków, aby stosowali szczepionkę budzącą poważne zastrzeżenia natury etycznej, jeśli jest to sprzeczne z ich przekonaniami religijnymi lub moralnymi. Wezwali rządzących, aby zadbali o udostępnienie niekontrowersyjnej etycznie szczepionki alternatywnej, gdy zostanie ona opracowana.

Problem wykorzystania materiału biologicznego pochodzącego z niegodziwego źródła był już wcześniej przedmiotem analiz wielu bioetyków (Sanders, Giudice i Raffin 1993; Shorr 1994; Pruss 2004; 2006; Wong 2006; Orłowski 2011; McKenna 2018). Został również podjęty w instrukcji Kongregacji Nauki Wiary Dignitas personae: „Do badań naukowych oraz do produkcji szczepionek lub innych produktów bywają niekiedy wykorzystywane linie komórkowe, powstałe w wyniku niegodziwego zabiegu, wymierzonego przeciwko ludzkiemu życiu lub fizycznej integralności bytu ludzkiego. Związek z niesprawiedliwym działaniem może być bezpośredni lub pośredni. Wszystko to rodzi różnorakie problemy natury etycznej, związane ze współdziałaniem w złu i zgorszeniem” (Kongregacja 
Nauki Wiary 2008, 34). Dokument precyzuje, iż należy rozróżnić sytuację, kiedy naukowcy stosują materiał biologiczny z niegodziwego źródła, który został wyprodukowany poza ich ośrodkiem badawczym lub jest dostępny w sprzedaży. Istnieje również zróżnicowana odpowiedzialność tych, którzy korzystają ze szczepionek wyprodukowanych przy użyciu linii komórkowych niegodziwego pochodzenia. Ważne racje w niektórych przypadkach mogłyby po części usprawiedliwić moralnie wykorzystanie materiału biologicznego pochodzącego z niegodziwego źródła, jak na przykład zagrożenie życia dziecka może upoważnić rodziców do zastosowania takiej szczepionki. Pozostaje jednak zawsze moralny obowiązek, by wyrazić swój sprzeciw i zażąać od osób odpowiedzialnych za systemy opieki zdrowotnej, by dostępne były alternatywne rodzaje szczepionek (Kongregacja Nauki Wiary 2008, 35; Zespół Ekspertów ds. Bioetycznych Konferencji Episkopatu Polski 2020, 17).

W przypadku badań nad szczepionką przeciw COVID-19 koncernu Astra Zeneca należy zauważyć, że materiał biologiczny wykorzystany do produkcji preparatu nie pochodzi z aborcji wykonanej specjalnie do tego celu i w ostatnim czasie, lecz szczepionka ta opracowywana jest na hodowlach komórkowych z abortowanych płodów ludzkich sprzed prawie 50 lat. Chodzi tu o linię komórkową HEK-293, pochodzącą z ludzkich embrionalnych komórek nerki pobranej z abortowanego płodu żeńskiego, wytworzoną w 1973 r., obecnie wykorzystywaną szeroko w przemyśle biotechnologicznym, m.in. w pracach nad szczepionkami (Wong 2006, 473-477; Orłowski 2011, 81-82).

W 2005 r. Papieska Akademia Życia zajęła stanowisko w tej sprawie: „stosowanie szczepionek, których produkcja wiąże się z przerywaniem ciąży, jest co najmniej pośrednią, odległą, bierną współpracą materialną z aborcją i bezpośrednią, bierną współpracą materialną w zakresie ich sprzedaży. W odniesieniu do chorób, przeciwko którym nie ma dostępnych alternatywnych szczepionek, które byłyby akceptowalne etycznie, słuszne jest powstrzymanie się od ich stosowania, jeśli można to zrobić bez powodowania, że dzieci, a pośrednio cała populacja, zostaną narażone na znaczące ryzyko dla zdrowia. Jeśli jednak takie poważne zagrożenie dla zdrowia istnieje, szczepionki stwarzające problemy etyczne mogą być również stosowane tymczasowo. Na gruncie moralnym uzasadnieniem takiej decyzji jest fakt, że nie ma obowiązku unikania biernej współpracy materialnej w przypadku poważnych niedogodności. Ponadto znajdujemy w takim przypadku proporcjonalny powód, aby zaakceptować stosowanie tych szczepionek w obliczu niebezpieczeństwa sprzyjania rozprzestrzenianiu się czynnika chorobotwórczego ze względu na brak szczepień dzieci” (Pontificia Accademia per la Vita 2005).

W 2017 r. Papieska Akademia Życia wydała stanowisko w kwestii obowiązkowych szczepień (chodziło o obowiązkowe szczepienia przeciwko różyczce, śwince, odrze, ospie i wirusowemu zapaleniu wątroby typu A). Dokument przypomina, iż w przeszłości niektóre szczepionki mogły być przygotowywane z ko- 
mórek pochodzących z abortowanych ludzkich płodów, lecz obecnie używane do badań linie komórkowe są bardzo odległe (w czasie) od przeprowadzonych aborcji. Nie zachodzi więc bezpośredni związek między tymi działaniami, który implikowałby jednoznacznie negatywną etycznie ocenę ich użycia. Biorąc pod uwagę aspekt społeczny i moralny obowiązek zapewnienia szczepień ze względu na ochronę życia osób i całych społeczności (szczególnie osób najbardziej narażonych na konsekwencje zarażenia), Akademia stoi na stanowisku, iż można stosować wszystkie szczepionki, które są zalecane i obowiązkowe, mając moralną pewność sumienia, że użycie tych szczepionek nie oznacza bezpośredniego współdziałania z czynem aborcji. Pomimo tego, że wciąż aktualne pozostaje wezwanie, aby żadna ze szczepionek nie miała żadnego związku z działaniem aborcyjnym, Papieska Akademia Życia potwierdza, że szczepienia są wyrazem moralnej odpowiedzialności za życie i zdrowie dzieci, jak i całej populacji (Pontificia Accademia per la Vita 2017).

W podobnym tonie wypowiedziała się Kongregacja Nauki Wiary pod koniec 2020 r. w odniesieniu do szczepionek przeciwko COVID-19, które opracowano na podstawie linii komórkowych z tkanek pobranych z płodów poddanych wymuszonej aborcji: ,gdy nie są dostępne takie szczepionki przeciwko COVID-19, które nie budzą zastrzeżeń etycznych (na przykład w krajach, w których lekarzom i pacjentom nie są udostępniane szczepionki wolne od problemów etycznych lub w których dystrybucja jest trudniejsza ze względu na szczególne warunki przechowywania i transportu lub też gdy różne typy szczepionek są wprawdzie rozprowadzane $\mathrm{w}$ tym samym kraju, ale służby ochrony zdrowia nie pozwalają obywatelom wybierać szczepionki do zaszczepienia) jest moralnie dopuszczalne stosowanie szczepionek przeciwko COVID-19, które wykorzystały linie komórkowe z abortowanych płodów w procesie badawczym i produkcyjnym" (Kongregacja Nauki Wiary 2020, 2).

W świetle powyższych analiz podobną ocenę moralną należy zastosować do możliwej w przyszłości sytuacji, kiedy to na rynku (w danym państwie) będzie dostępna jedynie szczepionka, która została wyprodukowana przy użyciu komórek pochodzących z abortowanego przed wielu laty płodu ludzkiego. Jej użycie jest etycznie uzasadnione, jeśli w danym momencie nie będzie dostępnej na rynku alternatywnej szczepionki. Należy jednak wziąć pod uwagę sprzeciw osób, które nie będą chciały skorzystać ze szczepień, powołując się na sprzeciw własnego sumienia. Państwo w takiej sytuacji nie powinno zmuszać do poddania się szczepieniu oraz nie powinno w żaden sposób dyskryminować albo zastraszać osób, które nie skorzystają ze szczepień. Konsekwentnie, gdy zostanie wyprodukowana szczepionka, która nie będzie wzbudzać żadnych problemów moralnych, powinna przez system państwowy zostać dopuszczona jako alternatywa dla szczepionki, która wzbudza u wielu sprzeciw sumienia. 


\section{Problem kontrolowanego zakażenia wirusem ochotników ekspery- mentu}

Kolejny problem etyczny, związany również z próbami przyspieszenia prac nad opracowaniem skutecznej szczepionki, to problem kontrolowanego zakażenia wirusem zdrowych ochotników eksperymentu. Badania kontrolowanych zakażeń ludzi (controlled human infection studies - CHI) obejmują celowe wystawianie uczestników badań na działanie mikroorganizmów i / lub ich w ten sposób zarażanie. Nad zasadnością takiej procedury oraz szczegółowymi kryteriami, które miałyby regulować prowadzenie takich eksperymentów, debatowali naukowcy i bioetycy przy okazji poszukiwania szczepionek przeciwko malarii, Eboli czy wirusowi Zika (Gopichandran 2018; Rose 2018; Roestenberg i in. 2018; Matuschewski i Borrmann 2019; Jamrozik i Selgelid 2020), a w czasie pandemii koronawirusa debata ta nabrała nowej intensywności (Shah i in. 2020). Historyczne doświadczenia związane z przymusowym uczestnictwem różnych grup osób w eksperymentach medycznych nakazują dużą ostrożność w ocenie dobrowolnego uczestnictwa zgłaszających się do tego typu badań. Oprócz niedozwolonych eksperymentów medycznych wykonywanych w okresie międzywojennym w Turcji i w Stanach Zjednoczonych, potem w czasie II wojny światowej na więźniach hitlerowskich obozów koncentracyjnych, już na początku XX wieku stosowano eksperymenty polegające na zarażaniu wirusem specyficznych grup „ochotników", jakimi byli więźniowie, a wśród nich skazani na śmierć (Bogusz 1984, 166-168; 1985, 78; Rejnat 1997, 138-141). Poważne wątpliwości budziła ich rzekomo dobrowolna zgoda, szczególnie w wypadku osób skazanych na śmierć, którym obiecywano uniknięcie kary pod warunkiem zgłoszenia się na ochotnika do eksperymentu. Doświadczenia te skłoniły w 1964 r. Światowe Towarzystwo Medyczne do ogłoszenia tzw. Deklaracji helsińskiej, czyli zbioru zasad dotyczących prowadzenia badań klinicznych na człowieku. Deklaracja ta została połączona w 1975 r. z Kodeksem norymberskim i w ciągu następnych lat ulegała zmianom redakcyjnym. Obecnie obowiązująca wersja z 2013 r. (World Medical Association 2013) w punktach 19-20 mówi o osobach i grupach szczególnie narażonych na wykorzystanie podczas eksperymentów medycznych, którym należy zapewnić specjalnie zaplanowaną ochronę. W punktach 25-32 Deklaracja podejmuje temat świadomej zgody ochotnika eksperymentu. Należy zauważyć ostrzeżenie zawarte w Nowej Karcie Pracowników Stużby Zdrowia, aby w doświadczeniach klinicznych zwrócić szczególną uwagę na udział osób, które mogą być wrażliwe, bezbronne i podatne na wykorzystanie z racji zależności (np. studenci, więźniowie, wojskowi), niepewnej sytuacji społecznej i ubóstwa (bezdomni, bezrobotni, imigranci) albo niskiego poziomu kulturalnego, co sprawia trudności w uzyskaniu od nich świadomej zgody (Papieska Rada ds. Duszpasterstwa Służby Zdrowia 2017, 107). Czy wolontariusze z tych grup rekrutujący się do udziału w eksperymencie są rzeczy- 
wiście ochotnikami, którzy podejmują osobiście wolną decyzję, czy może pewne okoliczności zewnętrzne wymuszają taką zgodę na udział w badaniach?

Zwolennicy kontrolowanego zakażenia wirusem (CHI) osób zdrowych przekonują, iż w niektórych sytuacjach (np. pandemii) istnieją szczególnie mocne argumenty przemawiające za prowadzeniem takich badań w celu opracowania szczepionki. Zauważają jednak, że nie zwalnia to z zachowania szczególnej uwagi w kwestiach etycznych związanych z projektowaniem i prowadzeniem takich eksperymentów. Są nimi: potencjalne bezpośrednie korzyści dla uczestników; ryzyko związane z eksperymentalnymi badaniami dla wolontariuszy i osób trzecich; kwestia świadomej zgody; problem zapłaty (zwrócenia kosztów) dla uczestników badań; zaangażowanie społeczeństwa. Istnieje więc z jednej strony silne etyczne uzasadnienie przeprowadzenia dobrze zaprojektowanych badań kontrolowanego zakażenia ludzi wirusem, lecz z drugiej strony wymaga to szczególnie starannego rozważenia niektórych kwestii etycznych (Jamrozik i Selgelid 2020, 797-798). CHI mogą przyspieszyć opracowywanie nowych szczepionek i terapii. $\mathrm{Na}$ ich korzyść przemawia to, iż badania takie są znacznie krótsze i tańsze niż tradycyjne sposoby badań nad wynalezieniem szczepionek (Roestenberg, Kamerling i de Visser 2018b; Sauerwein, Roestenberg i Moorthy 2011). Znacznie mniejszej liczbie osób trzeba podać także szczepionkę eksperymentalną (która w tradycyjnym sposobie przeprowadzania badań też może okazać się niebezpieczna lub nieskuteczna). CHI mogą również zapewnić unikalny wgląd w interakcję między organizmem a patogenem (Roestenberg i in. 2018a). Dla wielu bioetyków badania takie co do zasady są etycznie akceptowalne, jeśli tylko spełnione zostaną podstawowe kryteria etyczne odnoszące się do badań klinicznych (Hope i McMillan 2004; Bambery i in. 2016).

Z perspektywy katolickiej celowe wystawianie uczestników badań na działanie mikroorganizmów lub ich kontrolowane zakażenie w celu opracowania szczepionki w czasie pandemii można uzasadnić, odwołując się do zasady miłości i solidarności. Życie fizyczne jest dobrem podstawowym, warunkującym wszystkie pozostałe, nie wyczerpuje jednak wartości osoby i nie jest najwyższym dobrem. Istnieją dobra wyższe, ze względu na które może być słuszne, a w niektórych przypadkach konieczne, narażenie się na niebezpieczeństwo jego utraty (Papieska Rada ds. Duszpasterstwa Służby Zdrowia 2017, 89). Człowiek w perspektywie ewangelicznej realizuje się jako dar z siebie dla innych. Oczywiście, nie może on dysponować arbitralnie swoim ciałem i zdrowiem swojego organizmu, ale może z mądrością i roztropnością poszukiwać takiej realizacji woli Bożej w swoim życiu, która jest gotowa ponieść ryzyko choroby, a nawet śmierci, dla dobra innych (Faggioni 2004, 180-181). Musi być to jednak w pełni wolna i świadoma decyzja osoby zgłaszającej się do takiego eksperymentu, w żaden sposób niewymuszona przez innych, motywowana jedynie miłością, wykluczająca chęć zarobku lub wzbogacenia się na uczestnictwie w badaniach. 


\section{Problemy etyczne związane $z$ dostępnością i zastosowaniem szcze- pionki}

Wraz z pojawieniem się szczepionki na rynku pojawiają się kolejne problemy etyczne, na które trzeba zwrócić uwagę. Wcześniej w artykule zasygnalizowano problem wykorzystania materiału z niegodziwego źródła przy opracowywaniu szczepionki. W momencie, w którym będzie ona dostępna w ramach powszechnych szczepień, pojawia się problem, czy taka szczepionka może być obowiązkowa? Czy państwo może zmuszać obywateli do przyjęcia szczepionki, która budzi sprzeciw ich sumienia? Wydaje się zasadne, aby obywatele mieli w takim przypadku możliwość skorzystania z wyboru, który w żaden sposób nie będzie skutkował na ich niekorzyść (w życiu zawodowym i społecznym, np. w miejscu pracy, w korzystaniu z pomocy medycznej itp.). Powinno dążyć się do tego, aby na rynku były dostępne inne preparaty, które nie budzą wątpliwości etycznych oraz aby każda osoba miała prawo wybrać taką wersję szczepionki, która nie budzi w niej sprzeciwu sumienia.

Kolejnym problemem, z którym trzeba będzie się zmierzyć, to kwestia dystrybucji i dostępności szczepionki (por. Commissione Vaticana COVID-19 e Pontificia Accademia per la Vita 2020, 10-12). Zatwierdzony preparat nie będzie od razu dostępny dla wszystkich chętnych, powstaje więc problem ustalenia ścisłych kryteriów, według których będzie on aplikowany poszczególnym osobom. Należy wziąć tu pod uwagę grupy szczególnego ryzyka, które w pierwszej kolejności powinny zostać poddane szczepieniom (pracownicy służby zdrowia, osoby chore i o zmniejszonej odporności, osoby starsze, opiekujący się chorymi i seniorami itp.).

W szerszej perspektywie społecznej, międzynarodowej należy dostrzec problem dostępności szczepionek dla ludzi najuboższych, wykluczonych, dla państw Trzeciego Świata. Zwracał na to wielokrotnie uwagę papież Franciszek. Ojciec święty stoi na stanowisku, iż szczepionka nie może być jedynie własnością kraju ani laboratorium, które ją stworzy. Powinna ona przyczyniać się do dobra wspólnego na całym świecie i stanowić „dziedzictwo całej ludzkości”. Podczas jednej ze środowych audiencji (19.08.2020) przypomniał o opcji preferencyjnej na rzecz ubogich, także w kontekście opracowywania szczepionki na COVID-19: „Opcja preferencyjna na rzecz ubogich, ten wymóg etyczno-społeczny, który wynika z miłości Boga (por. LS 158) [Encyklika Laudato si-M.S.], daje nam impuls, by pomyśleć i zaplanować gospodarkę, w której osoby, a zwłaszcza najubożsi, byliby w centrum. Zachęca nas również do zaprojektowania lekarstwa na wirus, dając pierwszeństwo tym, którzy najbardziej go potrzebują. Smutne byłoby, jeśli w dostępie do szczepionki na COVID-19 pierwszeństwo mieli najbogatsi! Smutne byłoby, jeśli taka szczepionka stałaby się własnością takiego czy innego państwa, gdyby nie była powszechna, dla wszystkich" (Franciszek 2020a). W Bożonarodzeniowym Orędziu Urbi et Orbi papież zaapelował do przywódców 
państw, przedsiębiorców, organizacji międzynarodowych, aby promowali współpracę, a nie konkurencję w kwestii szczepień. Franciszek upomniał się o szczepionki dla wszystkich, zwłaszcza dla najsłabszych i potrzebujących w różnych częściach świata (Franciszek 2020d). Istnieje zatem ,imperatyw moralny dla przemysłu farmaceutycznego, rządów i organizacji międzynarodowych zapewnienia, aby szczepionki, które są skuteczne i bezpieczne z medycznego punktu widzenia, a także etycznie akceptowalne, były dostępne także dla krajów najbiedniejszych, i to w taki sposób, który dla nich nie będzie uciążliwy. W przeciwnym razie brak dostępu do szczepionek, stałby się kolejnym motywem dyskryminacji i niesprawiedliwości, który skazuje kraje biedne na trwanie w ubóstwie sanitarnym, ekonomicznym i społecznym" (Kongregacja Nauki Wiary 2020, 6).

Dostęp do szczepionki powinien być powszechny, a obecny kryzys wymaga współpracy międzynarodowej na szeroką skalę. Państwa bogatsze, dysponujące środkami finansowymi i medycznymi, powinny pomóc (w myśl zasady pomocniczości) państwom uboższym, aby miały one dostęp do szczepień w czasie pandemii.

\section{Zakończenie}

Przegląd problematyki etycznej związanej z przygotowywaniem szczepionki na COVID-19, prowadzeniem badań klinicznych na ludziach, jak również z fazą szczepień w czasie pandemii, pokazuje, że jest to temat bardzo złożony i wymagający interdyscyplinarnego podejścia. Na różnych etapach badań pojawiają się bowiem zagadnienia, które dotyczą wielu różnych kwestii - poczynając od materiału biologicznego wykorzystywanego w przygotowaniu szczepionki, samej metodologii i organizacji prowadzenia badań w czasie pandemii oraz kwestie, które ujawniają się w momencie dostępności szczepionki na rynku, jak chociażby problem dystrybucji preparatu, zasady ustalenia pierwszeństwa szczepień dla grup szczególnie narażonych. Nie można pominąć ważnej kwestii interesów różnych firm i państw, które zainwestowały w badania nad wynalezieniem szczepionki. W kontekście globalnej pandemii kwestie finansowe nie mogą jednak stanowić przeszkody w dostępności przyszłej szczepionki dla ubogich ludzi, dla ubogich państw. Pandemia ma wymiar ogólnoświatowy, sytuacja wymaga więc, aby antidotum, którego poszukują sztaby naukowców, miało także zasięg światowy. Jak pisał papież Franciszek w encyklice Fratelli tutti: „Pamiętajmy, że nikt nie ocala się sam, że można się ocalić tylko razem" (Franciszek 2020, 32).

W świetle przeprowadzonych analiz należy stwierdzić, iż temat szczepień z moralnego punktu widzenia został pogłębiony w oficjalnych dokumentach Kościoła, które ukazały się w czasie pandemii. Urząd Nauczycielski Kościoła podjął problematykę szczepień i wyjaśniał moralne kwestie z tym związane w szerokiej perspektywie etycznej (problem pochodzenia materiału biologicznego wykorzy- 
stanego do produkcji szczepionek, problemy etyczne związane z dostępnością i zastosowaniem szczepionek, solidarność i współpraca międzynarodowa przy opracowywaniu i dystrybucji szczepionek). Refleksja teologiczna mniej miejsca poświęciła zagadnieniom metodologii i organizacji badań medycznych, które były źródłem sporów i debaty bioetycznej, szczególnie w początkowej fazie pandemii, gdy wytworzone w ekspresowym tempie szczepionki wchodziły do użycia. Warto również pogłębić od strony teologiczno-moralnej temat kontrolowanego zakażenia wirusem ochotników eksperymentu, który to proceder był szeroko stosowany w fazie klinicznej opracowywania szczepionek przeciw COVID-19.

Przeprowadzone analizy ukazują, iż pojawienie się na rynku finalnego produktu medycznego, jakim jest szczepionka, nie zawsze będzie wolne od dylematów moralnych związanych z jego użyciem. Pozostaje mieć nadzieję, że zarówno w pracach nad szczepionką przeciw COVID-19, jak również w przyszłych pracach nad innymi szczepionkami, zachowane zostaną najwyższe standardy etyczne, dzięki którym szczepienia nie będą budzić problemów natury moralnej u osób, które będą się im poddawać.

\section{ETHICAL DIMENSION OF RESEARCH AIMED AT DEVELOPMENT AND APPLICATION OF COVID-19 VACCINE}

\section{SUMMARY}

The recent pandemics unleashed by SARS-CoV-2 has given rise to a COVID-19 vaccine race and once again raised moral questions that are valid with every research and study carried out to find a vaccine for infectious diseases from which we still lack protection. This Article presents ethical problems related to the process of developing the vaccine at the research and development stage as well as ethical issues concerning distribution and availability of the vaccine once it is available on the market. International documents, i.a. of the World Health Organization and the Church as well as the discussion taking place in bioethical circles indicate that the topic is of crucial importance and should not be overlooked at the stage of research and development for a new vaccine. The paper outlines the most important ethical issues related to it: risk proportionality, informed consent to participate in an experiment, the use of biological material of illicit origin, the question of methodology and organization of medical research during pandemics, the issue of controlled infection of volunteers with the virus, ethical and social dilemmas related to availability and use of the vaccine, especially for the poor - people and countries. An overview of ethical concerns related to development of COVID-19 vaccine, human clinical trials and the vaccination phase during pandemics illustrate the complexity of this issue and its need for an interdisciplinary approach. 
Keywords: COVID-19, pandemic, vaccine, medical experiments, the ethics of medical research

Słowa kluczowe: COVID-19, pandemia, szczepionka, eksperymenty medyczne, etyka badań medycznych.

\section{BIBLIOGRAFIA}

Bambery, Ben i in. 2016. Ethical criteria for human challenge studies in infectious diseases. Public Health Ethics, 9 (1), 92-103. DOI: 10.1093/phe/phv026.

Bogusz, Józef. 1984. Etyczne granice eksperymentu klinicznego. Studia Philosophiae Christianae, 20 (2), 165-177.

Bogusz, Józef. 1985. Zasady deontologiczne związane z postępami wiedzy lekarskiej. W: Etyka $i$ deontologia lekarska, red. Tadeusz Kielanowski, 77-116. Warszawa: PZWL.

Comensoli, Peter A. 2020. A Letter to the Faithful Regarding Development of a COVID-19 Vaccine. Dostęp: 27.10.2020. https://mediablog.catholic.org.au/a-letter-to-the-faithful-regardingdevelopment-of-a-covid-19-vaccine/\#more-8597.

Commissione Vaticana COVID-19 e Pontificia Accademia per la Vita. 2020. Vaccino per tutti. 20 punti per un mondo più giusto e sano. Dostęp: 28.12.2020. http://www.humandevelopment.va/ content/dam/sviluppoumano/news/Vaccine\%20IT\%20EN\%20ES\%20-\%20Paper\%20DSSUI-PAV dec\%202020.pdf.

Davies, Glenn N. i Anthony Fisher i Makarios. 2020. Call for "ethically uncontroversial" COVID vaccine. Dostęp: 15.11.2020. https://sydneyanglicans.net/news/call-for-ethically-uncontroversial-covid-vaccine/50486.

Eyal, Nir i Marc Lipsitch i Peter G. Smith. 2020. Human Challenge Studies to Accelerate Coronavirus Vaccine Licensure. Journal of Infectious Diseases, 221 (11), 1752-1756. DOI: 10.1093/ infdis/jiaa152.

Faggioni, Maurizio P. 2004. La vita nelle nostre mani. Manuale di Bioetica teologica. Torino: Edizioni Camilliane.

Fisher, Anthony. 2020. Let's not create an ethical dilemma. Dostęp: 27.10.2020. https://www.catholicweekly.com.au/archbishop-fisher-op-lets-not-create-an-ethical-dilemma/.

Franciszek. 2020a. Catechesi - "Guarire il mondo": 3. L'opzione preferenziale per i poveri e la virtù della carità. Dostęp: 27.10.2020. http://www.vatican.va/content/francesco/it/audiences/ 2020/documents/papa-francesco_20200819_udienza-generale.html.

Franciszek. 2020b. Discorso ai membri della Fondazione "Banco Farmaceutico". Dostęp: 27.10.2020. http://www.vatican.va/content/francesco/it/speeches/2020/september/documents/ papa-francesco 20200919 banco-farmaceutico.html.

Franciszek. 2020c. Encyklika ,Fratelli tutti”.

Franciszek. 2020d. Messaggio Urbi et Orbi. Dostęp: 28.12.2020. http://www.vatican.va/content/ francesco/it/messages/urbi/documents/papa-francesco_20201225_urbi-et-orbi-natale.html.

Gopichandran, Vijayaprasad. 2018. Controlled human infection models for vaccine development: Zika virus debate. Indian Journal of Medical Ethics, 3 (1), 51-55. DOI: 10.20529/ IJME.2017.093.

Hope, Tony i John McMillan. 2004. Challenge studies of human volunteers: Ethical issues. Journal of Medical Ethics, 30 (1), 110-116. DOI: 10.1136/jme.2003.004440.

Jamrozik, Euzebiusz i Michael J. Selgelid. 2020. Ethical issues surrounding controlled human infection challenge studies in endemic low-and middle-income countries. Bioethics, 34 (8), 797-808. DOI:10.1111/bioe.12802. 
Jan Paweł II. 2003. Ad sodales Academiae pro vita. Acta Apostolicae Sedis, 95 (9), 589-592.

Kongregacja Nauki Wiary. 1987. Instrukcja „Donum vitae”.

Kongregacja Nauki Wiary. 2008. Instrukcja „Dignitas personae”.

Kongregacja Nauki Wiary. 2020. Nota na temat moralnej oceny stosowania niektórych szczepionek przeciw COVID-19. Dostęp: 22.12.2020. https://episkopat.pl/kongregacja-nauki-wiaryopublikowala-dokument-nt-szczepionek-przeciwko-covid-19/.

Leone, Salvino. 2007. Nuovo manuale di bioetica. Roma: Città Nuova.

London, Alex i Jonathan Kimmelman. 2020. Against pandemic research exceptionalism. Science, 368 (6490), 476-477. DOI: 10.1126/science.abc1731.

Matuschewski, Kai i Steffen Borrmann. 2019. Controlled Human Malaria Infection (CHMI) Studies: Over 100 Years of Experience with Parasite Injections. Methods in molecular biology (Clifton, N.J.), 2013, 91-101. DOI: 10.1007/978-1-4939-9550-9_7

McKenna, Kyle Christopher. 2018. Use of Aborted Fetal Tissue in Vaccines and Medical Research Obscures the Value of All Human Life. Linacre Quarterly, 85 (11), 13-17. DOI: $10.1177 / 0024363918761715$.

Międzynarodowa Rada Harmonizacji Wymagan Technicznych Dla Rejestracji Produktów Leczniczych Stosowanych u Ludzi. 2016. Zasady dobrej praktyki klinicznej E6 (R2). Dostęp: 15.11.2020. https://www.gcppl.org.pl/Portals/2/advertisings/ICH_GCP_E6_R2_wersja_polska_FINAL.pdf

Orłowski, Tomasz. 2011. Szczepionki produkowane na liniach komórkowych pochodzenia płodowego - problemy etyczne. Studia Redemptorystowskie, 9 (1), 75-90.

Papieska Rada ds. Duszpasterstwa Służby Zdrowia. 2017. Nowa Karta Pracowników Stużby Zdrowia.

Plotkin, Stanley A. i Arthur Caplan. 2020. Extraordinary diseases require extraordinary solutions. Vaccine, 38 (24), 3987-3988. DOI: 10.1016/j.vaccine.2020.04.039.

Pontificia Accademia per la Vita. 2005. Riflessioni morali circa $i$ vaccini preparati a partire da cellule provenienti da feti umani abortiti. Dostęp: 27.10.2020. https://www.amicidilazzaro.it/ index.php/riflessioni-morali-circa-i-vaccini-preparati-a-partire-da-cellule-provenienti-da-fetiumani-abortiti/.

Pontificia Accademia per la Vita, Ufficio Nazionale per la Pastorale della Salute (CEI), Associazione Medici Cattolici Italiani. 2017. Nota circol'uso dei vaccini. Dostęp: 27.10.2020. http://www. academyforlife.va/content/pav/it/the-academy/activity-academy/note-vaccini.html.

Pontificia Accademia per la Vita. 2020a. Pandemia e fraternità universale. Dostęp: 27.10.2020. http://www.academyforlife.va/content/dam/pav/documenti\%20pdf/2020/Nota\%20Covid19/ Nota\%20su\%20emergenza\%20Covid-19_ITA_.pdf.

Pontificia Accademia per la Vita. 2020b. L'humana communitas nell'era della pandemia: riflessioni inattuali sulla rinascita della vita. Dostęp: 27.10.2020. http://www.vatican.va/roman_curia/ pontifical_academies/acdlife/documents/rc_pont-acd_life_doc_20200722_humanacomunitas-erapandemia it.html.

Pruss, Alexander. 2004. Cooperation with past evil and use of cell-lines derived from aborted fetuses. Linacre Quarterly, 71 (4), 335-350. DOI: 10.1080/20508549.2004.11877730.

Pruss, Alexander. 2006. Complicity, fetal tissue, and vaccines. National Catholic Bioethics Quarter$l y, 6$ (3), 461-470. DOI: 10.5840/ncbq20066330.

Rejnat, Eugeniusz. 1997. Etyczne dylematy eksperymentów medycznych. Mazowieckie Studia Humanistyczne, 3 (2), 133-146.

Roestenberg, Meta i in. 2018a. Experimental infection of human volunteers. Lancet Infectious Diseases, 18 (10), e312-e322. DOI: 10.1016/S1473-3099(18)30177-4.

Roestenberg, Meta i Ingrid M.C. Kamerling i Saco J. de Visser. 2018b. Controlled human infections as a tool to reduce uncertainty in clinical vaccine development. Frontiers in Medicine, 5, Artykuł 297, 1-8. DOI: 10.3389/fmed.2018.00297. 
Rose, Anurandha. 2018. The ethics of volunteer selection and compensation in Controlled Human Infection Models in India. Indian Journal of Medical Ethics, 3 (4), 285-289. DOI:10.20529/ IJME.2018.084.

Sanders, Lee M. i Linda Giudice i Thomas A. Raffin. 1993. Ethics of Fetal Tissue Transplantation. Western Journal of Medicine, 159 (3), 400-407.

Sauerwein, Robert W. i Meta Roestenberg i Vasee S. Moorthy. 2011. Experimental human challenge infections can accelerate clinical malaria vaccine development. Nature reviews. Immunology, 11 (1), 57-64. DOI: 10.1038/nri2902.

Sgreccia, Elio. 2007. Manuale di bioetica. Volume 1. Fondamenti ed etica biomedica. Milano: Vita e Pensiero.

Shah, Seema K. i in. 2020. Ethics of controlled human infection to address COVID-19. Science, 368 (6493), 832-834. DOI: 10.1126/science.abc1076.

Shorr, Andrew F. 1994. Abortion and fetal tissue research: some ethical concerns. Fetal Diagnosis and Therapy, 9 (3), 196-203. DOI: 10.1159/000263931.

Waligóra, Marcin. 2020. Etyka badań klinicznych podczas pandemii COVID-19. Filozofia w praktyce, 6, Artykuł 8, 1-4. Dostęp: 27.10.2020. https://www.diametros.iphils.uj.edu.pl/fwp/article/ view/1623/1416.

Watt, Helen. 2020. COVID-19 vaccines and the use of foetal cells. Dostęp: 27.10.2020. http://www. bioethics.org.uk/images/user/covidbriefing2.pdf.

Wong, Alvin. 2006. The Ethics of HEK 293. National Catholic Bioethics Quarterly, 6 (3), 473-495. DOI: $10.5840 /$ ncbq20066331.

World Health Organization. 2000. Operational Guidelines for Ethics Committees that Review Biomedical Research. Dostęp: 15.11.2020. https://www.who.int/tdr/publications/documents/ethics. pdf

World Health Organization. 2020a. Key criteria for the ethical acceptability of COVID-19 human challenge studies. Dostęp: 27.10.2020. https://apps.who.int/iris/bitstream/handle/10665 /331976/WHO-2019-nCoV-Ethics_criteria-2020.1-eng.pdf?ua=1.

World Health Organization. 2020b. Ethical standards for research during public health emergencies: Distilling existing guidance to support COVID-19 R\&D. Dostęp: 27.10.2020. https://apps. who.int/iris/bitstream/handle/10665/331507/WHO-RFH-20.1-eng.pdf?sequence=1\&isAllowe$\mathrm{d}=\mathrm{y} \& u a=1$.

World Health Organization. 2020c. Guidance for research ethics committees for rapid review of research during public health emergencies. Dostęp: 27.10.2020. https://apps.who.int/iris/bitstream/handle/10665/332206/9789240006218-eng.pdf?ua=1.

World Medical Association. 2013. World Medical Association Declaration of Helsinki Ethical Principles for Medical Research Involving Human Subjects. Journal of the American Medical Association, 310 (20), 2191-2194. DOI: 10.1001/jama.2013.281053.

Zespół Ekspertów ds. Bioetycznych Konferencji Episkopatu Polski. 2020. Stanowisko dotyczace szczepionek. Dostęp: 28.12.2020. https://episkopat.pl/zespol-ekspertow-ds-bioetycznych-kepws-szczepionek-przeciwko-covid-19/.

Marcin Szczodry - kapłan, doktor, adiunkt w Instytucie Nauk Teologicznych Uniwersytetu Szczecińskiego. Prowadzi badania w zakresie teologii moralnej i bioetyki. e-mail: marcin.szczodry@usz.edu.pl 